\title{
Guerrilla Marketing - Innovative and Futuristic Approach towards Marketing
}

\author{
Dr. Amit Kumar Khare
}

Director PGDM \& Associate Professor, Rameshwram Institute of Technology and Management Lucknow, India

\begin{abstract}
In this economic and conventional world, company doing conventional things unconventionally. Company is doing their advertising for the consumer demands through creativity and their budget. In recent times bulk marketing in the sales process of company gain maximum benefit at the minimum cost. Therefore, the term "Guerrilla marketing" is used to describe an unusual system of promotions on a very low budget, relying on time, energy, and the imagination instead of big marketing budgets. This is nothing but to describe aggressive, unusual marketing methods generically. The paper serves to explore the uses and needs for the Guerrilla marketing approach and how they are superior and different from the traditional marketing tactics. In this paper we will describe cost cutting and bearing maximum impact on the consumer will also be highlighted. This paper also will try and understand the terminology, its literature, application to the small business and profitability.
\end{abstract}

Keywords - Sales marketing, Guerrilla Marketing, Creativity, Small Business, Advertising.

\section{OBJECTIVES:}

- To understand the Principles and tips for effective Guerrilla Marketing Approach

- To study the Guerrilla Marketing Practices in India its examples and its future

\section{INTRODUCTION}

Every now and then consumers are encumbered with ample of advertisements and marketing campaigns by various firms. Hence, for a firm the challenge is not just differentiating itself and get noticed and identified in the midst of the competitors, but also break through the clutter. Generic competition leaves the firms fighting for the common customer wallet. Thus, traditional marketing approaches no longer remain the powerful tools for the firms, steering to the emergence of guerrilla marketing concept.

Guerrilla Marketing is specifically geared for the small business and entrepreneur. In this competitive, swift, and overcrowded marketplace more companies are resorting to the use of guerrilla marketing, which, simply stated, uses unconventional marketing methods to gain conventional results. Like in warfare, guerrilla tactics are used when an organization is small and/or does not have the resources to deal with a large, entrenched enemy head on. Instead of believing that single marketing weapons such as advertising or a website work, guerrillas know that only marketing combinations work. The paper would serve to understand this process in a greater depth. It also makes an attempt to study the associated marketing trends for innovative marketing.

\section{Sales Marketing}

Sales marketing is the term derived from marketing to sale the product, in other term sale is nothing but a volume whereas Marketing is an environment where consumer agreed to buy the product. In traditional Indian market sales marketing method is used to create the hype in the market to sale the product in bigger volume to larger buyer of consumer. Sales is also a part of guerllia marketing which ultimately gives maximum profit to the company after buying of product by the customer.

\section{About "Guerrilla Marketing"}

Every year, millions of money was wasted in marketing, most of those messages either misunderstood by the consumers, or targeted to the wrong audience. Marketing is expensive back in 1980s. Compared to the giant corporations, the small business owners do not have enough money to waste in the ineffective marketing campaigns. They want to use the limited budgets to the right targets. Rather than shouting vague messages to vague audiences, marketers are whispering just the right word in just the right years.

Since 1984, Jay Levinson has written more than 30 books about guerrilla marketing. His books appear in 62 languages and are required readings for MBA courses worldwide. Jay Levinson now has been often referred as father of guerrilla marketing. However, back in 1984, even the author did not predict that the concept of guerrilla marketing from the book would completely change the way of marketing. For the first time, the small business could garner as much attention from the consumers as the giant corporation because of guerrilla marketing. Those different, personal, or even weird 
advertisements in 80 s pioneered a marketing revolution for the next century.

In 1990s, guerrilla marketing had entered the mainstream. More and more major corporations started to adopt guerrilla marketing theory in their marketing campaigns. Even the consumers started to notice the difference in the corporations' marketing strategies. For example, 13 the TV commercials' focuses started to switch from promoting the products to pleasing the audience. The 30seconds TV commercial used to spending the whole 30 seconds selling products, now they only used the last 3 seconds to present the product and the first 27 seconds to make audience laugh.

\section{REVIEW OF LITRETURE}

Wensen (2008) asserts nowadays that one can win the battle for the consumer's attention by being smarter and more creative than his/her opponent, instead of spending more money for TV commercials than his/her competitor does. His definition of Guerrilla marketing is a broad one and an unexpected brand program through alternative media. Guerrilla marketing includes, for example, Guerrilla marketing, ambush marketing, buzz marketing and also events, but Guerrilla marketing is far more than the definition. It is a mentality too, because the mentality of thinking is outside the box and thinking for solutions for communications problems in a broader way, instead of thinking in terms of just TV commercials. Traditional advertising on $\mathrm{TV}$, radio, print and even traditional outdoor advertising is not what is meant by guerrilla marketing. Guerrilla marketing is a way of thinking. He says that the study have to use that way of thinking at the beginning of the strategic process. Guerrilla marketing is achieving conventional goals, such as profits and joy, with unconventional methods, such as investing energy instead of money (Kaden, 2007). Prévot (2006) defined guerrilla marketing as means to gain maximum exposure through minimal cost to the company. Most importantly, as the father of guerrilla marketing, Jay Levinson defined it as unconventional marketing intended to get maximum results from minimal resources (Levinson, 2003). Guerrilla marketing is more about matching marketers' creativity than matching marketing budgets. Guerrilla marketing can be as different from traditional marketing as guerrilla warfare is from traditional warfare. Rather than marching their marketing dollars forth like infantry divisions, guerrilla marketers snipe away with their marketing resources for maximum impact (Cohen, 2000). Regina and Galer-Unti (2009) expresses some of the principles of Guerrilla marketing configured to aid in health advocacy efforts. The basic tactics of Guerrilla marketing are to substitute innovation and creativity for the staid and status quo methods of advertising Compared to traditional marketing, guerrilla marketing has different focuses in terms of marketing theory. Firstly, guerrilla marketing believes that marketing plan should be part of business plan. The traditional marketing theory finds product life cycle as the guideline of marketing planning. The product life cycle typically covers four stages including introduction, growth, maturity, and decline; each stage calls for different marketing strategies (Kotler \& Keller, 2009). However, the product life cycle is not necessary the business life cycle. Guerrilla marketing planning focuses on the growth of the business, highlighting the business' competition advantages. According to Levinson (1999), marketing plan may mention all the business benefits, but it concentrates on the big guns, the guns lacking from the major competitors' arsenals. Furthermore, the goal of guerrilla marketing plan is making profits by making the product or service interesting. Guerrilla marketing uses profits as the only yardstick for measuring its performance; it based on psychology-laws of human behaviour-more than on marketers' own guesswork and judgment (Levinson, 1999). Rather than traditional marketing which heavily focus in explaining product functions, guerrilla marketing presents marketing campaign as an exploration journey of product followed by the rules of customer behaviour. It brings in imagination, energy into the product with a consumer point of view. Secondly, guerrilla marketing uses different marketing weapons. Guerrilla marketers believe the most powerful weapon comes from the business itself. According to Levinson (1999), a mandatory weapon for guerrilla marketers is the business's competitive advantages. The competitive advantage is the unique identity of every business; it is the key to set the business apart from the competition.

Moreover, the additional mandatory weapon for guerrilla marketers is the power of information.

In this information driven society, guerrilla marketers also believe in sharing knowledge with customers. Guerrilla marketers also believe that business grows with the competitors as long as the industry grows by the product knowledge of customers. Levinson (1999) points out that the more generosity the company shows to public, the better likelihood they'll see it reflected in its growing profitability. Thirdly, guerrilla marketers import their attitude in their every marketing act. The attitude of a guerrilla marketer is dramatically different from that of a non-guerrilla marketer, which is why customers feel the difference (Levinson, 1999). It is important that the attitude of the business should be unique and consist to its competitive advantage. In addition, the consistency of attitude should be in every marketing detail, from splendid national TV commercials to every piece of direct mail. Levinson (1999) points out that the attitude of 
business must come shining through in all marketing materials. It needs to come across by what the marketers say, how they say it, where they say it and how frequently they say it.

\section{GUERRILLA MARKETING AND ITS PRINCIPLES}

Bold, creative, unexpected and engaging are the characteristics that can be associated with Guerrilla marketing. Underneath are the principles underlying the Guerrilla marketing:

Presence - This principle asserts finding ways to make the firm known at all times - may be the chat rooms, forums, discussion boards, e-mail, radio, magazines, blogs, Yellow Pages, streets, everywhere. Make your presence feel Multiple-unit franchising strategy of the franchisors like Pizza Hut, Start Bucks can be correlated with this principle - where by the strategy of the firm is to have multiple outlets in close proximity attracting consumer attention and discouraging would-be competitors. They are making their presence felt by the consumers in particular geography by setting up multiple units in the given geography.

Activity - This principle asserts the firm to be aware of opportunities to make the product known at all times and act on them. A Charity Awareness Campaign by ITC - There are still millions who only dream of school - ITC fulfills its corporate social responsibility by helping some of them realize this dream. For every four ITC Classmate notebooks bought, ITC contributes Re. 1 to its rural development initiative that supports, among other projects, primary education in villages. ITC motivates the consumers by evoking the spirit in them that they can be proud that their contribution is a part of serving the dreams of millions.

Energy - Guerrilla marketing emphasizes on continual marketing - '3600 Marketing'. It emphasizes on creating tremendous marketing and sales results by using creativity instead of money.

Networks - It asserts always looking to make contacts and develop networks - an emphasis on importance of relationship. IWC Big Pilot Watch Bus Guerrilla Marketing The more number of consumers who will get into the bus will get exposed to the handles in the bus carrying the dummy prototype of IWC Big Pilot watch which will be a memorable brand experience, they in turn will generate buzz to others.

Smart - Smart tactics should be adopted by the firm not to offend the customers or turn them off. It emphasizes usage of smart sales and marketing without resorting to the loud, tacky and even obnoxious marketing that inundates today's consumers.
TIPS FOR DOING GUERRILLA MARKETING:

* Bold: It emphasizes on standing out from amongst the crowd of messages, the advertising clutter the customers are faced with. It is all about differentiating the message and how it is delivered. Being bold doesn't imply that the message and the way it is delivered be intrusive, pushy or annoying, rather it should be passionate and noticeable.

* Creative: Apply the power of creativity to create a lasting impression on the audience/customers which will in turn do viral marketing.

* Unexpected: Average customers are inundated with thousands of messages exposed to them and most people thus ignore vast majority of advertising directed to them. This is thus important for the sales and marketing efforts be unexpected by being innovative, unique, new and fresh in how the message is presented.

* Engaging:Interactive marketing encapsulates customer involvement in the sales and marketing process. Guerrilla marketing emphasizes on this so as to hold customers' attention and allow them to absorb the message.

Some of the advantages of Guerrilla Marketing are enlisted underneath:

* Flexible because of it small scale nature it can be adapted very quickly, it is relatively easy to respond to change.

* Low cost is one of its founding principles. It is ideal for the firms who do not possess massive marketing budget. It best utilizes the marketing dollars smartly and effectively.

* Targeted It is targeted to reach the target market thus, reducing waste and ineffectiveness.

* Simple Many of its methods are simple and easy to use and implement.

Some of the non-conventional advertising methods encompasses, use of internet, pop-up ads, use of internet technology, word of mouth, stickers, badges, blogs, demonstration, free consultation, SMS messaging, peer marketing, generating mystery or intrigue or other illegal methods like graffiti ads, spray paint logos, bill stickers.

\section{EXAMPLES OF GUERRILLA MARKETING:}

Anando Milk, from India, wanted to increase milk consumption among children, so the McCann Erikson Agency came up with this amazingly creative ad placed on one of Mumbai's buildings, where you can see a child strong enough $-\mathrm{a}$ benefit of the milk, of course- to move part of the building itself.To demonstrate Pantene's claim of "really strong hair", three rapunzel-style stunts were staged in downtown Toronto for two days, where live male climbers went up over three different oversized ponytails.

Big Bazaar's guerrilla advertising smartly targeting Westside by giving the message in the hoardings - Keep 
West-aside, Make a smart choice.Thus, firms can opt for bold, innovative, engaging, unique, marketing strategies to differentiate them and become noticeable in the clutter, so as to catch the attention of the audience, make the message and the brand name memorable and repercussionally inducing viral marketing. Guerrilla marketing is thus, the smart choice.

\section{Markting's Objectives:}

Guerrilla marketing is specifically geared for the small business and entrepreneur. It should be based on human psychology instead of experience, judgment, and guesswork. Instead of money, the primary investments of marketing should be time, energy, and imagination. The primary statistic to measure your business is the amount of profits, not sales. The marketer should also concentrate on how many new relationships are made each month. Create a standard of excellence with an acute focus instead of trying to diversify by offering too many diverse products and services. Instead of concentrating on getting new customers, aim for more referrals, more transactions with existing customers, and larger transactions. Forget about the competition and concentrate more on cooperating with other businesses. Guerrilla Marketers should always use a combination of marketing methods for a campaign. Use current technology as a tool to empower your ( from article Guerrilla Marketing, 2012 )

\section{GUERRILLA MARKETING IN INDIA:}

\section{Packaging:}

The Guerrilla marketing efforts uses minimum cost but creates maximum impact. Packaging is becoming a popular 'media vehicle' for Guerrilla communication. Nestle's Maggi noodles has cleverly used packaging for spreading awareness about the new offering from its brand mix (Bedi, 2010). When a consumer opens the packet of 'Maggi Masala Noodles' and takes out the pack of tastemaker (which is inside the noodles' packet), he come across the message written on the tastemaker's pack- 'try new curry masala'. The message is a part of Guerrilla communication as firstly, it doesn't cost extra to the marketer. Secondly, least effort is put in by the marketer for communicating the message but the impact created on the consumers is quite considerable and they may try out the new product variant.

\section{Product's design}

Marketer pay immense attention to the product's design, shape etc. and the intricacies involved therein. Nokia's Bajaj's Pulsar has a huge fuel tank symbolizing male's bicep and 'communicating' that the bike is as powerful as a muscular male.

\section{Colour, perception and communication}

Colours of the packets and the product 'communicate' a lot. Bath soaps in pink and white colours are considered as feminine and are meant for females. The green dot on the pack of the products communicates that the ingredients of the product are vegetarian whereas the red dot communicates that the ingredients of the product are non-vegetarian. TVS Scooty Pep's bright and vibrant colours 'communicates' the vehicle is for girls. It had also launched the range of 99 colours of TVS Scooty Pep to lure the female youths.

\section{Process of building guerrilla marketing campaign}

Guerrilla marketing starts with careful planning and recommends 10 steps, including In terms of being legal, the most common pitfalls of Guerrilla marketing are trespassing on private property, defacing private or public property, and not getting permission from the property owners when required.

- Analysis of market

- Research of market

- Plan future course of action

- Brainstorming

- Know the boundaries Perform brand test

- Sweating of details

- Know the legal Aspects

- Plan integrity

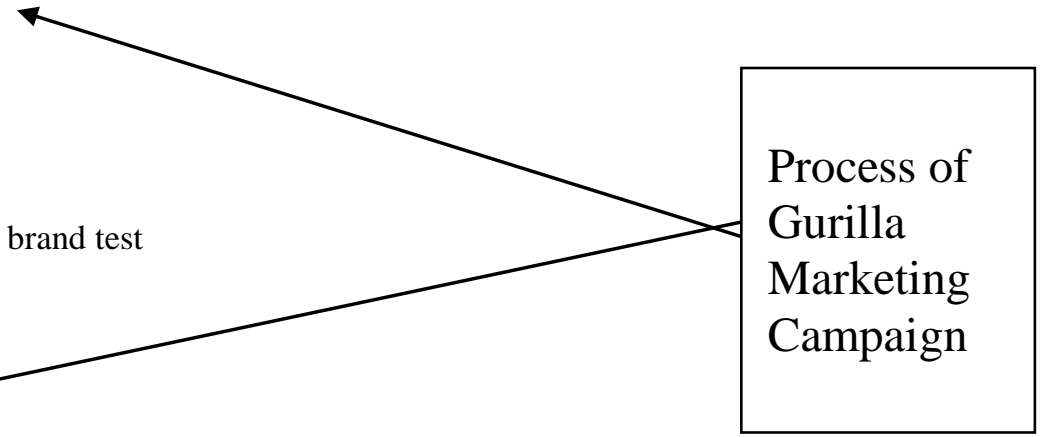

- Do not judge the result

\section{MODES OF GUERRILLA MARKETING:}

Guerrilla marketing encompasses marketing approaches such as buzz marketing, viral marketing, and grassroots marketing. Guerrilla marketing employs give-aways and contests, special events and "happenings", and street teams and other highly visible marketing teams.

There is a list of some methods for guerrilla marketing that can be used. These methods are: 
- Product give-aways, free demonstrations and consultations

- Intrigue-generating mystery to engage customers

- Peer marketing-bringing people with similar interests

- $\quad$ SMS text and video messaging

- Roach Baiting and buzz marketing-using actors

- Live commercials-using people to do live commercials

- Bill stickers-an approach used to promote DJ's and clubs

1. Turner Television Network: Push The Red Button

To Add Drama: Do you remember watching Turner Television Network's "Push the Red Button to Add Drama" guerrilla campaign last year? Well they are back! And this time with a whole new thrilling drama in the middle of the road. To launch it's new series and movie channel, TNT added crazy action packed drama to the innocent passers-by' usual day. If someone dared to press the RED button, they were in for roller coaster ride. No! Seriously. This is one of my favourite guerrilla advertising examples and really appreciate the marketing team behind it to have to balls to pull off something like this.

2. Delite-O-Matic: Human Lab Rats Run For Fantastic Delites: Fantastic Delights is an Australian snack company and is recently known for its fun guerrilla marketing campaigns. In order to test human snack behaviour, Fantastic Delites wanted to check if anyone would subject themselves to a lab experiment. Whoever chose to be the subject out of the audience had to run in the wheel fast as they could to reach the top of a bar. And if they did, they'd win a prize. A bold guerrilla example which was fun to take part, watch and was well worth the effort.

3. Coca Cola: Generous Atm Machine: A Coca Cola ATM machine in Spain that dispenses 100 euros for free, on the condition that the receiver shares the reward with someone. This came as an addition to the overall Coke's vision of spreading happiness. And talking about Coca Cola, this is another small campaign execution amplified on-line.

4. Lipton Ice Tea: World's First Floating Vending Machine: Lipton came up with the world's first floating vending machine promoting the "Never Lose Your Cool" campaign. And yes, it was actually a floating vending machine where beach-goers had to swim through the sea to get a drink. In the pre-hype to the campaign, Lipton released information through its Facebook page of a cargo ship going down and vending machines getting lost in the sea. The users were encouraged to guess the locations to get a chance to win a prize. An audience relevant guerrilla advertising example that was based on insights.
5. Lipton Ice Tea: Tea-Mometer: What happens when you combine ice tea and a thermometer: you get a TEAmometer! Lipton takes another spot in the 13 best guerrilla advertising examples of this year so far for the same campaign - "Never Lose Your Cool." The TEAmometer was a thermo activated, can shaped vending machine that made use of touch screen technology to detect people's body temperature. People who had high body temperature and heart rate were being awarded free Lipton Ice Tea; and not only that! They encouraged people to increase their body temperature by hoola hooping and dancing around. Fun, engaging and some serious viral content!

6. Coke Zero: The Airline Takeover: Coca Cola wanted to prove that Coke Zero doesn't taste any different from regular Coke. Of course there is a difference between the two, but it is hardly noticeable by the regular Coke consumer. Check the video below to see how strongly the message was conveyed in the most simplest and cheapest possible fashion:

7. Japanese Retailer Uses Kinect Powered Mannequins: We always hear about Japanese being ahead in technology, and this guerrilla advertising example proves it quite well. Already fascinated by the robot culture, United Arrow apparel store in Japan hooked up the mannequins on their store display with Microsoft Kinect. The result? The shoppers and passers-by had a great time making the mannequins mimic their moves as a large crowd spent hours in front of the store.

8. M\&Ms Gangnam Style In Paris:Many brands and film makers tried their best to ride the success of the Korean pop star's hit song "Gangnam Style," since it became Youtube's most watched video ever... and M\&M was one of them. Five people dressed up as M\&M characters roamed around in the streets of Paris fooling with people, greeting them and dancing on Gangnam Style. A very simple street marketing example which turned out to be effective because these 5 characters managed to interact with people first hand and actually made hundreds of them dance to the Gangnam Style beat. 9. Tic Tac: France's Worst Breath Prank: I personally love flash mobs a lot, and this flash mob prank by Tic Tac is one of the best guerrilla marketing examples. A stranger approaches a random guy / girl in a busy walk friendly area to ask for directions. As soon as the person starts speaking, everyone in the vicinity faints. Not only everyone in the vicinity, but a big monitor around the corner suddenly turns on and shows that all people in the nearby areas are also fainting. The expressions on peoples faces are priceless as they have no clue what is going on and are shit scared. When the drama ends, one of the fainted people hands the person a pack of Tic Tac. Over dramatized but totally worth the effort. 
10. Coca Cola Spreads The Love On Valentines Day: This year on Valentine's Day Coca Cola decided not to come up with a formal Valentine's Day TVC. Instead, they issued a brief to independent film makers to come up with a campaign. Hugh Mitton from New Zealand picked the brief up and spread the love to as many couples as possible by tying Coke cans to red helium balloons that landed in front of them.

11. Coca Cola: Small World Machines: And yet another Coca Cola campaign that I have already shared. A small world machine that brings people of two countries, India \& Pakistan, together. These two countries are known to have a tensed relationship since the time of their partition and independence, and this light hearted Coke campaign sent a very strong message across: Common people want to live in harmony!

12. Coca Cola: The Happy Flags: And it seems like Coca Cola is on a never ending run of setting guerrilla advertising examples for others to follow. Denmark has been named as the world's most happiest nation by various surveys, and more recently by the UN. Coke clubbed this discovery with Denmark's tradition of greeting arriving passengers with Danish flags, and gave away free flags!

13. Heineken: The Negotiation: Last but not the least, Heineken extended their crazy attempts to target football fanatics through a nice guerrilla campaign. They secretly gave men a chance to watch the Champions League final, only on one condition: they had to convince their female counter parts to buy a pair of ordinary looking stadium seats at a ridiculously high price. This was my list of the 13 Best Guerrilla Advertising Examples of 2013 so far, and I hope you enjoyed it. Leave a comment below if you have any more cool examples to share. That's it from me today.

\section{CONCLUSION}

Since beginning, guerrilla marketing always brings inspiration to the marketers and especially small businesses. However big companies have definitely been quick enough to benefit out of this concept. It requires imagination instead of money from marketers to promote the products and services. It encourages community sharing from the marketers to their customers. It also recommends marketers to create joyful experience for customers by giving away surprises. All in all, guerrilla marketing can help any business build an innovative image for them.

\section{REFERENCES}

[1] C.Homburg, "Marketing management. StrategieInstrument -Umsetzung Unternehmensführung," 4th Edition, Springer/Gabler, Wiesbaden, 2012.
[2] Kaden. R. J. (2007). Guerrilla marketing research: Marketing research techniques that can help any business make more money. London and Philadelphia: Kogan Page.

[3] Levinson, J. C. (1984). Guerrilla marketing: Secrets for making big profits from your small business.Boston. Houghton Mifflin.

[4] Levinson, J. C. (1999). Mastering guerrilla marketing 100 profit-producing insights you can take to the bank. New York: Houghton Mifflin Company.

[5] Levinson, J. C. (2003). Guerrilla marketing for free: 100 no-cost tactics to promote our business and energize your profits. Houghton Mifflin Harcourt.

[6] Mughari, A. M. (2011), Analysis of guerrilla and traditional marketing integration in improving the productivity of organizational marketing in enterprises in Iran: A case study of Kaveh Industrial Estate in Iran, African Journal of Business Management, Vol. 5(3), pp. 944-948.

[7] Kotler, P. and Keller, K. L. (2009). A framework for marketing management. Upper Saddle River, New Jersey: Pearson Education, Inc.

[8] P. Kotler, G. Armstrong, J. Saunders and V. Wong, "Grundlagen des Marketing," 5th Edition, Pearson, Mün- chen, 2010

[9] Prévot, A. (2007). The Effects Of Guerrilla Marketing On Brand Equity, The Consortium Journal, 13(2), 33- 40.

[10] Regina. A and Galer-Unti, A (2009). Guerrilla Advocacy: Using Aggressive Marketing Techniques. Society for Public Health Education. Published by: http://www.sagepublications.com.

[11] Venkatraman, R. (2012) Guerrilla Marketing, paper presented at International Conference on Competitiveness \& Innovativeness in Engineering, Management and Information Technology (ICCIEMI-2012), January 29, 2012

[12] Wensen, H. V. (2008). Advantages of Guerrilla Marketing, EVP, Chief Guerrilla Officer Draftfcb Amsterdam. Podcast Transcript. 1(2): 2-5. 